\title{
DEVELOPMENT AND VALIDATION OF AN INDUSTRY 4.0 ADAPTATION POTENTIAL SCALE (4IRAPS)
}

\author{
Fikret SÖZBİLIR (1D* \\ Department of Business Administration, Faculty Economics and Business Administration, \\ Artvin Coruh University, Artvin, Turkey
}

Received 24 June 2020; accepted 11 January 2021

\begin{abstract}
The aim of this study was to develop a scale that can measure the potential of adapting to Industry 4.0, which refers to the fourth industrial revolution described as a combination of the innovation of various digital technologies rapidly developed in recent years. In addition, the reliability and validity of the Industry 4.0 Adaptation Potential (4IRAPS) is demonstrated. This research was conducted in two stages of a pilot and a main study. The data was collected from 174 participants enrolled in technical and management departments at the graduate and associate degree levels of two different universities. A 50-item questionnaire concerning Industry 4.0 prepared by experts experienced in this field was applied to the participants. As a result of a factor analysis, 30 items and 11 subscales with low a factor load and reliability level were removed from the questionnaire. The reliability and validity of 4IRAPS were verified by" the analyses via PLS-SEM. Finally, the remaining four sub-dimensions referring to Industry 4.0 were labelled as interested, effort for adaptation, readiness, and pessimism. This study developed the first scale of the industry 4.0 adaptation potential. The scale consists of four sub-dimensions and 17 items. It was determined that this scale was statistically reliable and valid.
\end{abstract}

Keywords: industry 4.0, adaptation potential, scale development, effort, pessimism about industry 4.0.

JEL Classification: J24, L84, M50, O14.

\section{Introduction}

Historically, based on the technological developments, the industrial process has been split into generations, namely Industry 1.0, 2.0 and 3.0, and the current industrial generation has been called Industry 4.0. In the latest era, industry and working life have been transformed, and the operation of the mechanical structure has been replaced by digital relations. In other words, machines communicate with each other and a huge system can be managed from the interface in a center. The management of such a complex technological structure and human

*Corresponding author. E-mail: fsozbilir08@hotmail.com 
workers within these structures requires significant competence, knowledge, and skills (Bauer \& Wee, 2015; Eberhard et al., 2017; Vaidya et al., 2018; Koca, 2020).

Bauer and Wee (2015) defined Industry 4.0 as the industrial process where production is digitized with developments, such as managing large areas with little power, a surprising increase in the processing power of high volume data gathered by the extensive and intensive network relationship within the enterprise, analytical and business intelligence, touch interfaces, augmented reality systems with human-machine interaction, advanced robotic systems, and $3 \mathrm{D}$ printing digital images that can be turned into physical output.

As can be inferred from the definition given above, the major components of Industry 4.0 are Cyber-Physical Systems (CPS), the Internet of Things (IoT), the Internet of Services (IoS), robotics, big data, cloud and cognitive computing and augmented reality (AR) (Sanders et al., 2016; Pereira \& Romero, 2017; Zhong et al., 2017; Xu et al., 2018; Ruppert et al., 2018). According to Bauer et al. (2018), Industry 4.0 provides significant advantages to business in terms of the increasing efficiency (47\%), decreasing errors (33\%), reducing costs $(33 \%)$, supporting staff (32\%), minimizing production time (31\%), and utilizing human-machine interfaces $(25 \%)$. It is considered that the importance of human resources in production decreases with the fourth industrial revolution (Industry 4.0). On the contrary, integrating individuals as managers in the production process to support continuous improvement in the process and outputs, create value added aspects, and prevent possible losses shows that importance of employees is greater than before (Vaidya et al., 2018). Due to the business technology created by the fourth industrial revolution, the skills required in the future are updated every year (Eberhard et al., 2017). For example, according to the research of the world economic forum, creativity, which was tenth in the top ten in the ranking of importance, moved up seven places in 2016 coming third (World Economic Forum, 2016), and in the research conducted in 2019 creativity ascended to the top in the of the soft skills list (Charlton, 2019). This mostly concerns university students and other job seekers hoping to find a job in the future or those wanting to be promoted to a good position.

Schmidt et al. (2015) conducted an empirical study on the potentials of use of Industry 4.0, with the participation of 592 experts in the information technology and manufacturing sector. The authors used a Likert scale consisting of six factors and the following 13 items, which were technology use $(n=5)$, production time improvement $(n=4)$, business process complexity $(n=1)$, level of automation $(n=1)$, mass customization $(n=1)$, and idle data $(\mathrm{n}=1)$. They found that four factors positively and significantly influenced the potential use of Industry 4.0 while the business process complexity negatively and significantly influenced the potential use of Industry 4.0; however, they did not find a significant relationship between level of automation and the potential use of Industry 4.0. Hamada (2019) surveyed 1062 owners and managers of firms in Japan, finding that the managers' lack of knowledge of technological developments resulted in decision-makers failing in Industry 4.0 adaptation.

Following a thorough review of the literature, no scale regarding the Industry 4.0 adaptation potential scale was found. Although Hamada (2019) used a scale in his research to measure decision-makers of firms' attitudes toward adaptation to Industry 4.0, his scale was designed to survey organizations and was not sufficient to measure individuals adaptation 
potential to Industry 4.0. This shortcoming prompted the need to develop and validate an appropriate scale. To fulfil this gap, this study was conducted for the purpose of developing a scale in this field that will contribute to academic studies and support practitioners in terms of employee's adaptation potential to Industry 4.0. It will also guide the provision of qualified human resources and determine their priorities. Furthermore, recommendation to universities will be made to encourage to prepare students for their future working life and the new labor market conditions.

\section{Method}

Mixed-methods methodology was used in the research. First, a qualitative method was used with the purpose of determining the content that should be included in the scale construct by researching the findings in the literature. In addition, the issue was discussed with two experts to create items for the test scale. Then, the quantitative method was administered to develop and validate the scale. SPSS v. 25 was used for data analyses. This study was undertaken in two parts: first, a test scale was applied to the participants as a pilot study, and second following the results of the pilot study, the items to be removed from the test scale were determined.

\subsection{Pilot study (first part)}

In order to develop the scale, a questionnaire was prepared to examine the factor structure and internal consistency of Industry 4.0 items and distributed to the voluntary participants. Reliability, validity and correlation analyses were carried out in order to simplify the scale by removing the items with low reliability and validity from the initial draft scale with 50 items. The pilot scale was conducted in stages, as in previous studies (Slavec \& Drnovsek, 2012). These stages are described below.

First stage: content domain specifications, item generation, and questionnaire development

Initially, the literature review related to Industry 4.0 was skimmed, and the prominent information about the subject was compiled. Based on the literature review of Industry 4.0, which included cloud computing, CPS, robots, and IoT 50 items were created and checked by two specialists who are knowledgeable in this field, and some statements were revised. To develop the scale to be used in the research, a 50 -item questionnaire was produced using a five-point Likert scale ranging from 1 (strongly disagree) to 5 (strongly agree).

Second stage: sampling, survey and data collection

The questionnaire developed in the first stage was applied to the determined sample. The suggested sample size is 40 participants for a pilot study that aims to assess the adequacy of a scale (Isaac \& Michael, 1995; Hertzog, 2008; Johanson \& Brooks, 2010). The sample of the current pilot study consisted of 50 students enrolled in Artvin Coruh University; 20 in the technical sciences department and 30 in the management sciences. Fifty questionnaire forms were distributed to the students, and all of them were completed. 


\section{Third stage: Dimensionality and reliability assessment}

An exploratory factor analysis (EFA) was conducted on the 20-item Industry 4.0 Adaptation Potential (4IRAPS) to improve the scale. The validity and reliability analyses of the test scale items were undertaken using the collected data, and the items with factor loads below 0.55 and reliability levels (Cronbach's alpha) below 0.70 were removed from the scale. The factor loads were maintained above 0.55 in order to increase validity, and the number of items was reduced in order to keep the participants engaged in the process of completing the questionnaire. Ensuring this was necessary to collect accurate data with a questionnaire that will be developed for use in future studies. Thirty relatively weak items were removed from the scale; thus, as a result of reliability and validity analyses, a 20-item scale with four subscales each consisting of five items was produced. The subscales and their reliability and factor loadings are shown in Tables 1 and 2.

At the completion of the pilot study, a scale was developed to measure the Industry 4.0 adaptation potential. This 20 -item five-point Likert scale ranging from 1 (Strongly disagree) to 5 (Strongly agree) and the factor loadings are given in Table 3.

Table 1. Reliability analyses results of the pilot study

\begin{tabular}{|c|c|c|c|c|c|c|c|}
\hline \multirow[b]{2}{*}{ Subscales } & \multirow{2}{*}{$\begin{array}{l}\text { Number } \\
\text { of Items }\end{array}$} & \multirow[b]{2}{*}{$\begin{array}{l}\text { Cronbach's } \\
\text { Alpha }(\alpha)\end{array}$} & \multicolumn{2}{|c|}{ Inter-Item Means } & \multicolumn{3}{|c|}{ Scale Statistics } \\
\hline & & & Correlation & Covariance & Mean & Variance & $\begin{array}{c}\text { Std. } \\
\text { Deviation }\end{array}$ \\
\hline $\begin{array}{l}\text { Interested in } \\
\text { Industry } 4.0\end{array}$ & 5 & 0.866 & 0.568 & 0.687 & 18.063 & 19.847 & 4.45501 \\
\hline $\begin{array}{l}\text { Effort for Adaptation } \\
\text { to Industry } 4.0\end{array}$ & 5 & 0.904 & 0.657 & 0.783 & 19.979 & 21.638 & 4.65165 \\
\hline $\begin{array}{l}\text { Readiness for } \\
\text { Industry } 4.0\end{array}$ & 5 & 0.729 & 0.349 & 0.350 & 13.740 & 11.991 & 3.46275 \\
\hline $\begin{array}{l}\text { Pessimism about } \\
\text { Industry } 4.0\end{array}$ & 5 & 0.791 & 0.428 & 0.711 & 16.167 & 22.482 & 4.74155 \\
\hline
\end{tabular}

Table 2. Subscales and factor analyses results of the pilot study

\begin{tabular}{|l|c|c|c|c|c|c|}
\hline \multirow{2}{*}{ Subscales } & \multirow{2}{*}{ KMO } & \multicolumn{3}{|c|}{ Bartlett's Test of Sphericity } & \multicolumn{2}{c|}{$\begin{array}{c}\text { Extraction Sums of } \\
\text { Squared Loadings }\end{array}$} \\
\cline { 5 - 8 } & & Approx. Chi-Square & df & $\begin{array}{c}\text { Sig. } \\
(p)\end{array}$ & Total & $\begin{array}{c}\% \text { of } \\
\text { Variance }\end{array}$ \\
\hline Interested in Industry 4.0 & 0.816 & 105.170 & 10 & 0.000 & 3.270 & 65.407 \\
\hline Effort for adaptation to Industry 4.0 & 0.867 & 147.306 & 10 & 0.000 & 3.639 & 72.782 \\
\hline Readiness for Industry 4.0 & 0.616 & 50.490 & 10 & 0.000 & 2.372 & 47.431 \\
\hline Pessimism about Industry 4.0 & 0.769 & 60.860 & 10 & 0.000 & 2.671 & 53.415 \\
\hline
\end{tabular}

Note: KMO: Kaiser-Meyer-Olkin, Measure of sampling adequacy. 
Table 3. The measurement scale developed through the pilot study and the factor loadings

\begin{tabular}{|c|c|c|c|c|c|}
\hline \multicolumn{2}{|c|}{$\begin{array}{c}\text { Subscales (Factors) } \\
\text { and items }\end{array}$} & $\begin{array}{c}\text { Factor loadings of } \\
\text { items }\end{array}$ & \multicolumn{2}{|c|}{$\begin{array}{c}\text { Subscales (Factors) } \\
\text { and items }\end{array}$} & $\begin{array}{c}\text { Factor loadings } \\
\text { of items }\end{array}$ \\
\hline 1 & \multicolumn{2}{|c|}{ Interested in Industry 4.0 (INT-IN4) } & 3 & \multicolumn{2}{|c|}{ Readiness for Industry 4.0 (REI4) } \\
\hline 1 & & 0.821 & 11 & & 0.566 \\
\hline 2 & & 0.722 & 12 & & 0.577 \\
\hline 3 & & 0.741 & 13 & & 0.674 \\
\hline 4 & & 0.712 & 14 & & 0.675 \\
\hline 5 & & 0.733 & 15 & & 0.571 \\
\hline 2 & & Effort for Adaptation to Industry $4.0($ EFADI4) & 4 & Pessimism about Industry 4.0 (PESIN4) \\
\hline 6 & & 0.820 & 16 & & 0.620 \\
\hline 7 & & 0.718 & 17 & & 0.587 \\
\hline 8 & & 0.734 & 18 & & 0.607 \\
\hline 9 & & 0.673 & 19 & & 0.788 \\
\hline 10 & & 0.808 & 20 & & 0.656 \\
\hline
\end{tabular}

\subsection{Main study (second part)}

The modified 20 -item scale was distributed to 200 students, and data was collected and analyzed to determine the final 4IRAPS.

\subsubsection{Procedures}

4IRAPS, which was developed with the pilot study, required a main study to ensure it is accurate in terms of reliability and validity. In the second part of this study, the final version of the scale was created. To achieve this, the scale was administered to a larger sample than that of the pilot study. The collected data was examined by a factor analysis, and the validity and reliability of the construct were assessed again (Crocker \& Algina, 1986; Johanson $\&$ Brooks, 2010). For this study, SPSS v. 25 was used for EFA. Structural equation modeling (SEM), which is a multivariate statistical method (Stein et al., 2012), was applied. For the confirmative factor analysis (CFA), SmartPLS 3, a statistical program using the partial leastsquare structured equation model (PLS-SEM), was utilized (Ringle et al., 2015).

\subsubsection{Sample}

The research data were collected from university students between November and December 2019. These students were selected from two universities in question as part of the entrepreneurship project and were preparing to enter the business world. In this respect, they were determined as a research sample that is thought to have awareness of industry 4.0. The 4IRAPS questionnaire was distributed to students studying in business administration, technical and engineering departments in Artvin Coruh University and Recep Tayyip Erdogan University in Turkey. A total of 174 students participated voluntarily in the survey with an $87 \%$ response rate. Of the respondents, $64(36.8 \%)$ were male and $110(63.2 \%)$ were female, with ages ranging from 18 to 25 years $(\mathrm{M}=22.04$; $\mathrm{SD}=3.80)$. The demographic characteristics of the participants are shown in Table 4. 
Participants' perceptions of the scale items, "which are the most popular occupations in the industry 4.0 process" and "what will be the impact of Industry 4 . to the workforce" are intended to provide an insight into how the participants interpret the Industry 4.0 process. In addition, whether they are proficient in any software language is an indicator of their digital skill, which is important for the future labor world. The perceptions of the respondents concerning these issues are shown in Table 5.

Table 4. Demographic characteristics of the participants

\begin{tabular}{|l|c|c|c|c|c|}
\hline Students from University & $\mathrm{N}$ & Percent (\%) & Gender & N & Percent (\%) \\
\hline Artvin Coruh University & 112 & 64.4 & Male & 110 & 63.2 \\
\hline $\begin{array}{l}\text { Recep Tayyip Erdogan } \\
\text { University }\end{array}$ & 62 & 35.6 & Female & 64 & 36.8 \\
\hline Total & 174 & 100.0 & Total & 174 & 100.0 \\
\hline \multicolumn{1}{|c|}{ Degree } & $\mathrm{N}$ & Percent (\%) & $\begin{array}{c}\text { Do you know any software } \\
\text { language? }\end{array}$ & N & Percent (\%) \\
\hline Undergraduate & 32 & 18.4 & Yes & 40 & 23.0 \\
\hline Graduate & 127 & 73.0 & No & 134 & 77.0 \\
\hline Postgraduate & 15 & 8.6 & Total & 174 & 100.0 \\
\hline Total & 174 & 100.0 & Educational Field \\
\hline Age Groups & $\mathrm{N}$ & Percent (\%) & Nepartments) & Percent (\%) \\
\hline $18-19$ & 47 & 26.9 & Business and Management & 77 & 44.3 \\
\hline $20-21$ & 56 & 31.6 & $\begin{array}{l}\text { Electronic, Mechatronic and } \\
\text { Machine Engineering }\end{array}$ & 41 & 23.5 \\
\hline 22 & 31 & 17.8 & Architecture & 25 & 14.4 \\
\hline 23 & 17 & 9.8 & Health Sciences & 14 & 8.0 \\
\hline 24 & 14 & 8.1 & Physical Science & 13 & 7.5 \\
\hline 25 & 10 & 5.8 & Psychology & 4 & 2.3 \\
\hline Total & 174 & 100.0 & Total & 174 & 100.0 \\
\hline
\end{tabular}

Table 5. The future perceptions of the respondents

\begin{tabular}{|l|c|c|l|c|l|}
\hline $\begin{array}{l}\text { What is the most important impact } \\
\text { of Industry 4.0 on the workforce? }\end{array}$ & $\mathrm{N}$ & $\begin{array}{c}\text { Percent } \\
(\%)\end{array}$ & $\begin{array}{l}\text { What is the most popular job } \\
\text { in the future? }\end{array}$ & $\mathrm{N}$ & $\begin{array}{c}\text { Percent } \\
(\%)\end{array}$ \\
\hline $\begin{array}{l}\text { The need for qualified workforce } \\
\text { increases }\end{array}$ & 51 & 29.3 & Software & 33 & 19.3 \\
\hline $\begin{array}{l}\text { The need for (unskilled) labor } \\
\text { decreases }\end{array}$ & 48 & 27.6 & $\begin{array}{l}\text { Electronic/ Mechatronic/ } \\
\text { Machine }\end{array}$ & 41 & 23.6 \\
\hline Doesn't affect employment & 29 & 16.7 & Management and Psychology & 34 & 19.5 \\
\hline $\begin{array}{l}\text { Provides flexible working } \\
\text { opportunity in terms of time and } \\
\text { space }\end{array}$ & 46 & 26.4 & Computer and Space Sciences & 18 & 10.4 \\
\hline Total & 174 & 100.0 & $\begin{array}{l}\text { Digital Technologies and } \\
\text { Artificial Intelligent }\end{array}$ & 12 & 6.9 \\
\hline & & $\begin{array}{l}\text { Others (Nanotechnology, } \\
\text { Data Mining. Social Works) }\end{array}$ & 16 & 23.3 \\
\hline & & & \multicolumn{1}{|c}{ Total } & 174 & 100.0 \\
\hline
\end{tabular}


The students responded to the items based on the effects of Industry 4.0 on labor they perceived. As shown in Table 5, 73.6\% of the participants correctly evaluated the possible effects of Industry 4.0 on the workforce, consistent with the literature. In addition, most of the participants answered the question of "What is the most popular job in the future?" as data mining, software engineering, effective management skills, data analytics, computer system analysts, etc., which in consistent with the literature (Eberhard et al., 2017; Vaidya et al., 2018; Xu et al., 2018; Ruppert et al., 2018; Bauer et al., 2018; Koca, 2020).

\section{Results}

\subsection{EFA}

EFA is used to identify cross-relationships between inter-level variables and the principal component analysis determines the items which can be combined in a factor (Leech et al., 2005). A reliability analysis was performed to test whether the variables of each factor were consistent in measure. Additionally, the reliability analysis was used to determine the items with a low reliability level and evaluate the quality of the scale in accordance with Cronbach's alpha (Hair et al., 2014a).

In Table 7, the four factors revealed by the factor analysis using Varimax rotation explained $63 \%$ of the total variance. All the variables had a sufficient load on factors in which they were involved. Variable loadings of .50 or higher are accepted as practically significant (Hair et al., 2014a). While only one item (Item 15) had a loading of 0.539 , other variables have a greater load on the factors to which they belong (ranging from 0.619 to 0.880 ). Communality is another indicator of EFA, and the communality level of all variables have to be 0.50 or more in order to determine the total amount of a variable's common variance with other variables included in the analysis (Hair et al., 2014a). As a result of the factor analysis, the communality values of the items ranged from 0.506 to 0.804 . Unlike in the pilot study, one item ("Developing a different product or service makes me happy") moved from the second factor (Effort for adaptation to Industry 4.0) to the first factor (Interested in Industry 4.0 ), and the factor loads of some items decreased while those of others increased.

A reliability analysis is used to examine the consistency degree of a variable multiple measurements. Internal consistency, the most applied form of reliability, is provided by the item-to-total correlations exceeding 0.50 and inter-item correlations exceeding 0.30 (Hair et al., 2014a). In addition, the coefficient is the measure of scale reliability assessed with Cronbach's alpha with the suggested level being 0.70 or more (Cronbach, 1951; Gorsuch, 1983; Robinson et al., 1991; Field, 2009; Hair et al., 2014a). The results obtained from the reliability test of the current study were above the recommended levels.

A detailed examination of the scree plot test (Figure 1), in which the overall factor structure of the scale, factor eigenvalues, and eigenvalues were graphed against the factors showed that the scale, was best represented by four factors as predicted. 
Table 6. Factor analysis results

\begin{tabular}{|c|c|c|c|c|c|c|c|}
\hline \multirow{3}{*}{\multicolumn{2}{|c|}{$\begin{array}{l}\text { - Extraction Method: Principal } \\
\text { Component Analysis. } \\
\text { - Rotation Method: Varimax } \\
\text { with -Kaiser Normalization } \\
\text { - Rotation converged in } \\
6 \text { iterations. }\end{array}$}} & \multirow{2}{*}{$\mathrm{KMO}$} & \multicolumn{2}{|c|}{$\begin{array}{l}\text { Bartlett's Test of } \\
\text { Sphericity }\end{array}$} & \multicolumn{3}{|c|}{$\begin{array}{l}\text { Extraction Sums of } \\
\text { Squared Loadings }\end{array}$} \\
\hline & & & \begin{tabular}{|c|} 
Approx. \\
$X^{2}$
\end{tabular} & $\mathrm{df}$ & $\begin{array}{l}\text { Sig. } \\
(p)\end{array}$ & Total & $\begin{array}{c}\% \text { of } \\
\text { Variance }\end{array}$ \\
\hline & & 0.816 & 1721.667 & 190 & 0.000 & 12.741 & 63.705 \\
\hline \multirow{2}{*}{$\mathbf{N}$} & \multirow{2}{*}{\multicolumn{2}{|c|}{ Variables }} & \multicolumn{4}{|c|}{ Rotated Factor-Loading Matrix } & \multirow{2}{*}{ C } \\
\hline & & & 1 & 2 & 3 & 4 & \\
\hline 1 & \multicolumn{2}{|c|}{ Intelligent systems always interest me } & 0.839 & 0.138 & -0.022 & 0.009 & 0.724 \\
\hline 2 & \multicolumn{2}{|c|}{ I like to deal with digital devices } & 0.759 & 0.185 & 0.111 & 0.015 & 0.623 \\
\hline 3 & \multicolumn{2}{|c|}{$\begin{array}{l}\text { I agree with the philosophy of "Change is } \\
\text { the unchangeable rule of life", I am open to } \\
\text { innovations that Industry } 4.0 \text { will bring }\end{array}$} & 0.762 & 0.124 & 0.013 & -0.028 & 0.597 \\
\hline 4 & \multicolumn{2}{|c|}{ I have no problems in adapting to Industry 4.0} & 0.762 & 0.126 & 0.173 & -0.093 & 0.635 \\
\hline 5 & \multicolumn{2}{|c|}{ Industry 4.0 excites me about the future. } & 0.628 & 0.410 & 0.133 & 0.043 & 0.583 \\
\hline 6 & \multicolumn{2}{|c|}{$\begin{array}{l}\text { Developing a different product or service makes } \\
\text { me happy }\end{array}$} & 0.678 & 0.493 & 0.017 & 0.055 & 0.706 \\
\hline 7 & \multicolumn{2}{|c|}{$\begin{array}{l}\text { My adaptation process accelerates if I am } \\
\text { informed in detail about the innovations }\end{array}$} & 0.383 & 0.696 & -0.031 & 0.031 & 0.633 \\
\hline 8 & \multicolumn{2}{|c|}{$\begin{array}{l}\text { I must have data management skills to find a } \\
\text { place in the business world of the future }\end{array}$} & 0.411 & 0.619 & -0.076 & 0.095 & 0.567 \\
\hline 9 & \multicolumn{2}{|c|}{$\begin{array}{l}\text { In addition to the area I am currently studying, I } \\
\text { should develop myself in a different area. }\end{array}$} & 0.386 & 0.668 & -0.090 & 0.093 & 0.611 \\
\hline 10 & \multicolumn{2}{|c|}{$\begin{array}{l}\text { I must have the ability to analyze people's } \\
\text { behavior and abilities well and manage them } \\
\text { effectively. }\end{array}$} & 0.050 & 0.705 & 0.033 & -0.068 & 0.506 \\
\hline 11 & \multicolumn{2}{|c|}{ I have information about cyber physical systems } & -0.031 & 0.202 & 0.756 & 0.007 & 0.614 \\
\hline 12 & \multicolumn{2}{|c|}{ I have enough information about Industry 4.0} & 0.054 & -0.028 & 0.807 & -0.109 & 0.667 \\
\hline 13 & \multicolumn{2}{|c|}{$\begin{array}{l}\text { I have the technological knowledge to work on } \\
\text { Industry } 4.0\end{array}$} & 0.147 & -0.089 & 0.880 & 0.007 & 0.804 \\
\hline 14 & \multicolumn{2}{|c|}{$\begin{array}{l}\text { I have the areas and opportunities to work on } \\
\text { Industry } 4.0\end{array}$} & 0.064 & -0.196 & 0.845 & 0.092 & 0.765 \\
\hline 15 & \multicolumn{2}{|c|}{ I follow the technological developments closely. } & 0.474 & 0.048 & 0.539 & -0.065 & 0.572 \\
\hline 16 & \multicolumn{2}{|c|}{$\begin{array}{l}\text { I believe that artificial intelligence will surpass } \\
\text { human }\end{array}$} & 0.000 & 0.296 & 0.074 & 0.657 & 0.525 \\
\hline 17 & \multicolumn{2}{|c|}{$\begin{array}{l}\text { With the development of artificial intelligence, } \\
\text { human relations will regress. }\end{array}$} & 0.082 & 0.277 & -0.135 & 0.691 & 0.579 \\
\hline 18 & \multicolumn{2}{|c|}{$\begin{array}{l}\text { I think artificial intelligence as a threat to } \\
\text { humanity }\end{array}$} & 0.041 & -0.203 & 0.001 & 0.707 & 0.542 \\
\hline 19 & \multicolumn{2}{|c|}{$\begin{array}{l}\text { I'm afraid that artificial intelligence will one day } \\
\text { rule humanity }\end{array}$} & -0.117 & -0.058 & -0.082 & 0.867 & 0.776 \\
\hline 20 & \multicolumn{2}{|c|}{$\begin{array}{l}\text { I think devices will manage people with the } \\
\text { development of Industry } 4.0\end{array}$} & -0.036 & -0.075 & 0.079 & 0.836 & 0.712 \\
\hline
\end{tabular}

Note: 1: Interested in Industry 4.0, 2: Effort for Adaptation to Industry 4.0, 3: Readiness for Industry 4.0, 4: Pessimism about Industry 4.0, C: Communality, KMO: Kaiser-Meyer-Olkin, Measure of Sampling Adequacy. 
Table 7. Reliability analysis results

\begin{tabular}{|l|c|c|c|c|c|c|c|}
\hline & \multirow{2}{*}{ Subscales } & \multirow{2}{*}{$\begin{array}{c}\text { Number } \\
\text { of Items }\end{array}$} & $\begin{array}{c}\text { Cronbach's } \\
\text { Alpha }(\alpha)\end{array}$ & \multicolumn{2}{|c|}{ Inter-Item Means } & \multicolumn{3}{c|}{ Scale Statistics } \\
\cline { 4 - 8 } & & Correlation & Covariance & Mean & Variance & $\begin{array}{c}\text { Std. } \\
\text { Deviation }\end{array}$ \\
\hline $\begin{array}{l}\text { Interested in } \\
\text { Industry 4.0 }\end{array}$ & 6 & 0.880 & 0.563 & 0.552 & 23.590 & 23.046 & 4.801 \\
\hline $\begin{array}{l}\text { Effort for } \\
\text { Adaptation to } \\
\text { Industry 4.0 }\end{array}$ & 4 & 0.761 & 0.450 & 0.389 & 16.820 & 8.186 & 2.861 \\
\hline $\begin{array}{l}\text { Readiness for } \\
\text { Industry 4.0 }\end{array}$ & 5 & 0.845 & 0.522 & 0.627 & 13.680 & 18.544 & 4.306 \\
\hline $\begin{array}{l}\text { Pessimism about } \\
\text { Industry 4.0 }\end{array}$ & 5 & 0.815 & 0.465 & 0.807 & 16.050 & 24.771 & 4.977 \\
\hline
\end{tabular}

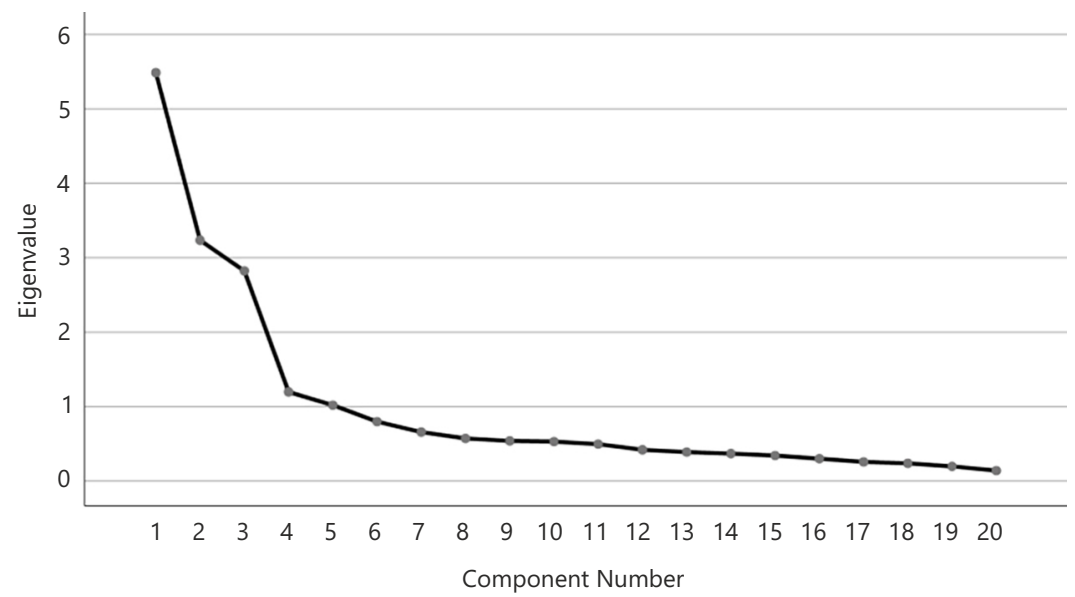

Figure 1. Scree plot for the final EFA

\subsection{CFA}

CFA is a method used frequently in scale development and validity analysis or verifying a predetermined structure. This method is a process for creating a latent variable (factor) based on the observed variables through a previously created model (Yaşlığlu, 2017). SmartPLS 3 software was used in the CFA (Ringle et al., 2015).

\subsubsection{Evaluation of measurement model}

CFA was conducted to evaluate the measurement model in terms of its internal consistency reliability and indicator reliability (composite reliability), convergent validity, and discriminant validity. The measurement model was developed by running the PLS algorithm via SmartPLS 3. As a result of the CFA of the model, which was first created in line with the EFA results (Figure 2), items 10, 18 and 20 were removed, and since the factor loads were low, the model was re-created (Figure 3). Revised model has 4 factor and 17 items. 


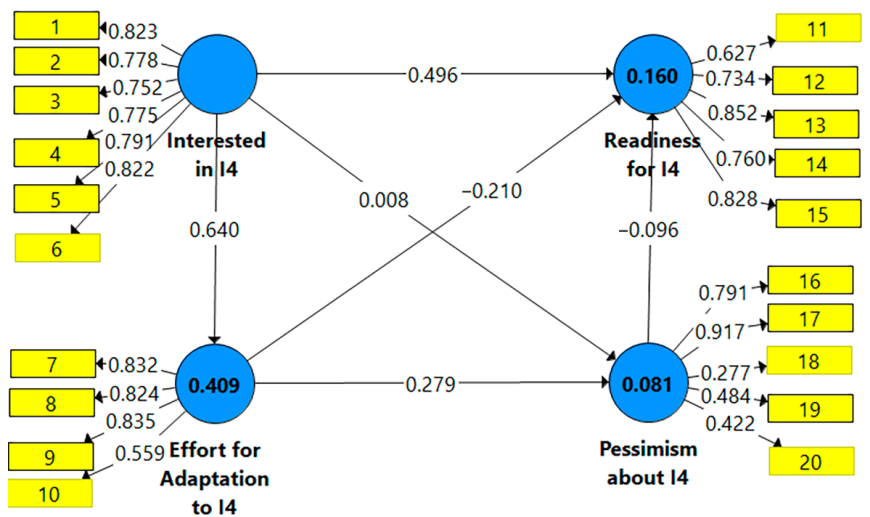

Figure 2. First measurement model

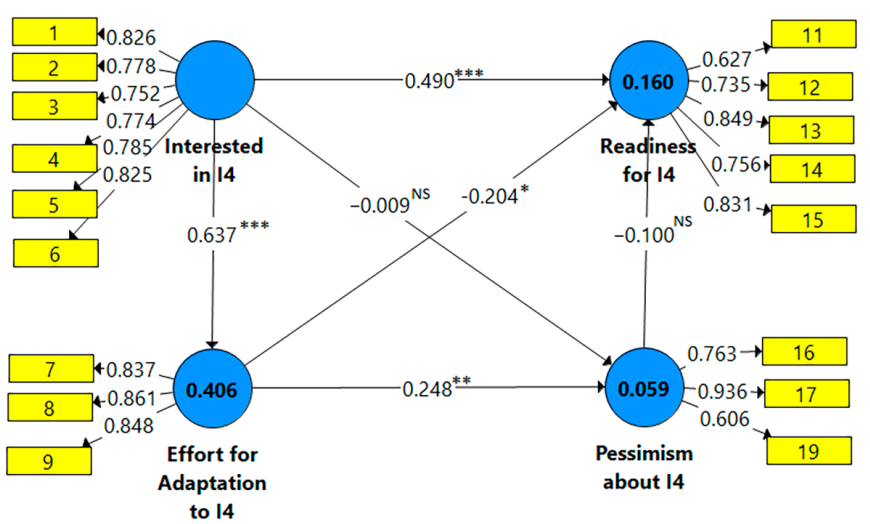

Figure 3. Revised measurement model

Note: ${ }^{* *} p<0.001 ;{ }^{* *} p<0.05 ;{ }^{*} p<0.10 ;{ }^{\text {NS }}=$ Non-significant; I4 = Industry 4.0.

\subsubsection{Convergent validity}

Firstly, the internal consistency (composite) reliability test was performed based on Cronbach's alpha and the outer loading of indicators (factor loadings) integrated into the convergent validity test. Convergent validity was established by considering the average variance extracted (AVE) values.

Internal consistency is verified by composite reliability and its value is expected to be over 0.70. The criterion of this analysis is Cronbach's alpha. Outer loading refers to the indicator reliability which should be higher than 0.708 . However, indicators with outer loadings above 0.40 are acceptable if it does not increase the threshold value of composite reliability and AVE; otherwise, they must be removed (Hair et al. 2014b). AVE should be 0.50 or more for convergent validity.

As shown in Table 8, all of the indicator's outer loadings, in the revised model (Figure 3) were higher than the suggested value of 0.708, except for two indicators (items 11 and 19) with loadings of 0.606 and 0.626 , respectively. These items were removed from the analysis, 
Table 8 . Convergent validity values

\begin{tabular}{|c|c|c|c|c|}
\hline Variables/Factors & Outer Loadings & AVE & Composite Reliability & Cronbach's Alpha $(\alpha)$ \\
\hline 1- INTIN4 & 0.826 & \multirow{6}{*}{0.625} & \multirow{6}{*}{0.909} & \multirow{6}{*}{0.881} \\
\hline 2- INTIN4 & 0.778 & & & \\
\hline 3- INTIN4 & 0.752 & & & \\
\hline 4- INTIN4 & 0.774 & & & \\
\hline 5- INTIN4 & 0.785 & & & \\
\hline 6- INTIN4 & 0.825 & & & \\
\hline 7- EFADIN4 & 0.837 & \multirow{3}{*}{0.721} & \multirow{3}{*}{0.886} & \multirow{3}{*}{0.806} \\
\hline 8- EFADIN4 & 0.861 & & & \\
\hline 9- EFADIN4 & 0.848 & & & \\
\hline 11- REIN4 & 0.627 & \multirow{5}{*}{0.583} & \multirow{5}{*}{0.874} & \multirow{5}{*}{0.832} \\
\hline 12- REIN4 & 0.735 & & & \\
\hline 13- REIN4 & 0.849 & & & \\
\hline 14- REIN4 & 0.756 & & & \\
\hline 15- REIN4 & 0.831 & & & \\
\hline 16- PESIN4 & 0.763 & \multirow{3}{*}{0.608} & \multirow{3}{*}{0.819} & \multirow{3}{*}{0.734} \\
\hline 17- PESIN4 & 0.936 & & & \\
\hline 19- PESIN4 & 0.606 & & & \\
\hline
\end{tabular}

Note: AVE - Average Variance Extracted. INTIN4: Interested in Industry 4.0; EFADIN4: Effort for adaptation to Industry 4.0; REIN4: Readiness for Industry 4.0; PESIN4: Pessimism about Industry 4.0.

and the model was re-tested. It was determined that they did not lead to an increase in composite reliability and AVE values. Since this study is exploratory research, items 11 and 19 did not need to be removed from the analysis (Hair et al., 2014b, pp. 104-107). All composite reliability values regarding latent variables were over the value of 0.7 (from 0.819 to 0.909 ) and highly reliable. Thus, all latent variables used in this model were considered as reliable. The AVE values of the latent variables were found to be above the threshold value of $0.50(0.583-0.721)$. According to these results, the convergent validity of the model was confirmed.

\subsubsection{Discriminant validity}

A discriminant validity analysis was conducted to determine whether a construct was statistically distinct from another. Cross-loadings of the indicators are defined as an outer loading of an indicator on a construct being higher than every other cross-loading with another construct. Some researchers have suggested using the Fornell-Larcker criterion (Fornell \& Larcker, 1981; Hair et al., 2014b), while others recommend the use of Heterotrait-Monotrait Ratio $\left(\operatorname{HTMT}_{.85}\right.$ ) as a new method (Henseler et al., 2015). In the current study, both approaches were used to assess discriminant validity in this study. The Fornell-Larcker criterion has generally been used in previous research in SEM analyses to compare square root of the AVE values with the correlations of the other latent variable. To verify discriminant validity, 
the square root of the AVE should be highest in other correlations in the same column (Hair et al., 2014b). According to Henseler et al. (2015), HTMT $_{.85}$ is a strong criterion since all simulation conditions reach the lowest specificity levels and provides superior performance to previous approaches. The $\mathrm{HTMT}_{85}$ ratio should be lower than 0.85 for an acceptable level. It was observed that the outer loading of the construct to which each variable was associated was higher than the other construct. The cross-loadings of the indicators are shown in Table 9.

Table 9. Cross-loading values

\begin{tabular}{|c|c|c|c|c|c|c|}
\hline \multirow{2}{*}{$\begin{array}{l}\text { Final } \\
\text { Num. }\end{array}$} & \multirow{2}{*}{$\begin{array}{l}\text { Initial } \\
\text { Num. }\end{array}$} & \multirow{2}{*}{ Variables } & \multicolumn{4}{|c|}{ Cross loadings } \\
\hline & & & INTIN4 & EFADIN4 & REIN4 & PESIN4 \\
\hline 1 & 1 & Intelligent systems always interest me & 0.826 & 0.475 & 0.246 & 0.083 \\
\hline 2 & 2 & I like to deal with digital devices & 0.778 & 0.448 & 0.342 & 0.160 \\
\hline 3 & 3 & $\begin{array}{l}\text { I agree with the philosophy of "Change is } \\
\text { the unchangeable rule of life", I am open to } \\
\text { innovations that Industry } 4.0 \text { will bring }\end{array}$ & 0.752 & 0.424 & 0.209 & 0.074 \\
\hline 4 & 4 & $\begin{array}{l}\text { I have no problems in adapting to } \\
\text { Industry } 4.0\end{array}$ & 0.774 & 0.398 & 0.345 & -0.010 \\
\hline 5 & 5 & Industry 4.0 excites me about the future. & 0.785 & 0.483 & 0.284 & 0.200 \\
\hline 6 & 6 & $\begin{array}{l}\text { Developing a different product or service } \\
\text { makes me happy }\end{array}$ & 0.825 & 0.712 & 0.226 & 0.161 \\
\hline 7 & 7 & $\begin{array}{l}\text { My adaptation process accelerates if I am } \\
\text { informed in detail about the innovations }\end{array}$ & 0.554 & 0.837 & 0.103 & 0.192 \\
\hline 8 & 8 & $\begin{array}{l}\text { I must have data management skills to } \\
\text { find a place in the business world of the } \\
\text { future }\end{array}$ & 0.531 & 0.861 & 0.076 & 0.188 \\
\hline 9 & 9 & $\begin{array}{l}\text { In addition to the area I am currently } \\
\text { studying, I should develop myself in a } \\
\text { different area. }\end{array}$ & 0.537 & 0.848 & 0.034 & 0.236 \\
\hline 10 & 11 & $\begin{array}{l}\text { I have information about cyber physical } \\
\text { systems }\end{array}$ & 0.137 & 0.075 & 0.627 & -0.047 \\
\hline 11 & 12 & $\begin{array}{l}\text { I have enough information about Industry } \\
4.0\end{array}$ & 0.103 & -0.051 & 0.735 & -0.100 \\
\hline 12 & 13 & $\begin{array}{l}\text { I have the technological knowledge to } \\
\text { work on Industry } 4.0\end{array}$ & 0.164 & -0.023 & 0.849 & -0.070 \\
\hline 13 & 14 & $\begin{array}{l}\text { I have the areas and opportunities to work } \\
\text { on Industry } 4.0\end{array}$ & 0.071 & -0.162 & 0.756 & -0.067 \\
\hline 14 & 15 & $\begin{array}{l}\text { I follow the technological developments } \\
\text { closely. }\end{array}$ & 0.494 & 0.231 & 0.831 & -0.043 \\
\hline 15 & 16 & $\begin{array}{l}\text { I believe that artificial intelligence will } \\
\text { surpass human }\end{array}$ & 0.130 & 0.166 & 0.047 & 0.763 \\
\hline 16 & 17 & $\begin{array}{l}\text { With the development of artificial } \\
\text { intelligence, human relations will regress. }\end{array}$ & 0.161 & 0.258 & -0.114 & 0.936 \\
\hline 17 & 19 & $\begin{array}{l}\text { I'm afraid that artificial intelligence will } \\
\text { one day rule humanity }\end{array}$ & -0.122 & -0.004 & -0.131 & 0.606 \\
\hline
\end{tabular}

Note: INTIN4: Interested in Industry 4.0; EFADIN4: Effort for adaptation to Industry 4.0; REIN4: Readiness for Industry 4.0; PESIN4: Pessimism about Industry 4.0. 
The Fornell-Larcker criterion results showed that the square root of AVE was higher than latent variable correlations in the same construct; therefore, all the constructs differed from each other, as shown in Table 12. The $\mathrm{HTMT}_{.85}$ values of each construct were lower than 0.85 ; thus, the discriminant validity of the measurement was established. The Fornell-Larcker criterion and $\mathrm{HTMT}_{.85}$ values are given in Table 10 .

Table 10. Fornell-Larcker criterion and $\mathrm{HTMT}_{.85}$ values

\begin{tabular}{|l|c|c|c|c|c|c|}
\hline \multicolumn{7}{|c|}{ Fornell-Larcker Criterion } \\
\hline Constructs & Mean & Std. Dev. & INTIN4 & EFADIN4 & REIN4 & PESIN4 \\
\hline INTIN4 & 0.626 & 0.037 & $\mathbf{0 . 7 9 1}$ & & & \\
\hline EFADIN4 & 0.720 & 0.046 & 0.637 & $\mathbf{0 . 8 4 9}$ & & \\
\hline REIN4 & 0.580 & 0.060 & 0.345 & 0.084 & $\mathbf{0 . 7 6 4}$ & \\
\hline PESIN4 & 0.555 & 0.119 & 0.149 & 0.242 & -0.077 & $\mathbf{0 . 7 8 0}$ \\
\hline \multicolumn{7}{|l|}{ HTMT $_{\text {. Values }}$ Values } \\
\hline Constructs & & & INTIN4 $^{\prime}$ & EFADIN4 & REIN4 & PESIN4 \\
\hline INTIN4 & & & & & & \\
\hline EFADIN4 & & & 0.734 & & & \\
\hline REIN4 & & & 0.294 & 0.174 & & \\
\hline PESIN4 & & & 0.213 & 0.244 & 0.156 & \\
\hline
\end{tabular}

Note: INTIN4: Interested in Industry 4.0; EFADIN4: Effort for adaptation to Industry 4.0; REIN4: Readiness for Industry 4.0; PESIN4: Pessimism about Industry 4.0; The square root of the AVE values is shown in bold.

\subsubsection{Evaluation of the structural model}

The structure model was evaluated in PLS-SEM using collinearity, path coefficient, coefficient of determination, and predictive relevance $\left(\mathrm{Q}^{2}\right)$ analyses. The collinearity test indicates whether there is a multicollinearity problem. A variance inflation factor (VIF) value higher than 5 as a result of the collinearity test indicates multicollinearity (Hair et al., 2014b). In this study, a linear regression analysis was performed to determine the important values for the validity of structural model. Effort for adaptation to Industry 4.0 (Factor 2), readiness for Industry 4.0 (Factor 3), and pessimism about Industry 4.0 (Factor 4) were included as the dependent variables in the structural model. Therefore, in terms of collinearity, the group of independent variables affecting each dependent variable was evaluated simultaneously, but listed separately. The results of the analysis revealed that all the VIF values were lower than threshold (5) and there was no multicollinearity problem. The collinearity analysis results are shown in Table 11.

The path coefficient represents the relationship between independent (exogenous) and dependent (endogenous) latent variables and defines the effect level of independent on dependent variables. The path coefficient is indicated by the symbol beta $(\beta)$. The significance level is important to indicate the relevance of path relationships between constructs, and this is determined by computing the empirical $t$ value by bootstrapping. To be significant, the $t$ value of a latent variable should be higher than $1.65(p=0.10)$. The structural model 
results revealed that INTIN4 had the strongest positive impact on EFADIN4 ( $\beta=0.637$; $p<0.001$ ). It was found that INTIN4 had no significant effect on PESIN4, and PESIN4 had no significant effect on REIN4. The remaining path coefficient values are shown in Table 12.

The coefficient of determination $\left(\mathrm{R}^{2}\right)$ is an important measure for assessing the structural model and indicating the collective impacts of the independent variables on the dependent variable(s). The $R^{2}$ value represents proportion of total variance in dependent variable explained by independent variables associated with it. $R^{2}$ values of 0.20 are accepted as a high level in social sciences research (Hair et al., 2014b). The $f^{2}$ effect size is a measurement performed by omitting the other variables from the model to determine the specific effect of one of the independent variables in the model. $f^{2}$ values of $0.02,0.15$, and 0.35 indicate a small, medium, and large effect size, respectively (Hair et al., 2014b).

The predictive relevance $\left(\mathrm{Q}^{2}\right)$ value was calculated by running the blindfolding procedure for an omission distance $(D=7)$ and using cross-validated redundancy via PLS-SEM (Chin, 1998; Henseler et al., 2009). It was found that INTIN4 had the strongest impact on EFADIN4 with regard to total effect, $f^{2}$ effect size, coefficient of determination $\left(R^{2}\right)$, and predictive relevant $\left(\mathrm{Q}^{2}\right)$ in the study. Two of the independent variables (exogenous), INTIN4 and EFADIN4, had a positive and significant effect on their dependent (endogenous) variables, EFADIN4, REIN4, and PESIN4. However, PESIN4 did not have a significant effect on

Table 11. Collinearity analysis results

\begin{tabular}{|l|c|l|c|l|c|}
\hline \multicolumn{2}{|c|}{ Dependent Variable: INTIN4 } & \multicolumn{2}{|c|}{ Dependent Variable: REIN4 } & \multicolumn{2}{|c|}{ Dependent Variable: PESIN4 } \\
\hline $\begin{array}{c}\text { Independent } \\
\text { Variable } \\
\left(1^{\text {st }} \text { Group }\right)\end{array}$ & VIF & $\begin{array}{c}\text { Independent } \\
\text { Variable } \\
\left(2^{\text {nd }} \text { Group }\right)\end{array}$ & VIF & $\begin{array}{c}\text { Independent } \\
\text { Variable } \\
\left(3 \mathrm{r}^{\mathrm{d}} \text { Group }\right)\end{array}$ & VIF \\
\hline INTIN4 & 1000 & INTIN4 & 1684 & INTIN4 & 1684 \\
\hline EFADIN4 & & EFADIN4 & 1749 & EFADIN4 & 1684 \\
\hline REIN4 & & REIN4 & & REIN4 & \\
\hline PESIN4 & PESIN4 & 1062 & PESIN4 & \\
\hline
\end{tabular}

Note: INTIN4: Interested in Industry 4.0, EFADIN4: Effort for adaptation to Industry 4.0, REIN4: Readiness for Industry 4.0, PESIN4: Pessimism about Industry 4.0.

Table 12. Path coefficient results

\begin{tabular}{|c|c|c|c|l|}
\hline $\begin{array}{c}\text { Path } \\
\text { Indep. Variab. } \rightarrow \text { Dep. Variab. }\end{array}$ & Path Coefficient $(\beta)$ & $t$-Values & $p$-Values & \multicolumn{1}{|c|}{ Results } \\
\hline INTIN4 $\rightarrow$ EFADIN4 & 0.637 & 90.001 & 0.000 & Positive Effect \\
\hline INTIN4 $\rightarrow$ REIN4 & 0.490 & 60.053 & 0.000 & Positive Effect \\
\hline INTIN4 $\rightarrow$ PESIN4 & -0.009 & 00.094 & 0.925 & Non-significant \\
\hline EFADIN4 $\rightarrow$ REIN4 & -0.204 & 10.921 & 0.056 & Negative Effect \\
\hline EFADIN4 $\rightarrow$ PESIN4 & 0.248 & 20.621 & 0.009 & Positive Effect \\
\hline PESIN4 $\rightarrow$ REIN4 & -0.100 & 10.275 & 0.203 & Non-significant \\
\hline
\end{tabular}

Note: INTIN4: Interested in Industry 4.0, EFADIN4: Effort for adaptation to Industry 4.0, REIN4: Readiness for Industry 4.0, PESIN4: Pessimism about Industry 4.0. 
Table 13. Results of the structural model

\begin{tabular}{|c|c|c|c|c|}
\hline $\begin{array}{c}\text { Path } \\
\text { Indep. Variab. } \rightarrow \text { Dep. Variab. }\end{array}$ & Total Effect & $f^{2}$ & $R^{2}$ & \multirow{2}{*}{$Q^{2}$} \\
\cline { 1 - 3 } INTIN4 $\rightarrow$ EFADIN4 & 0.637 & $0.684^{* *}$ & 0.405 & 0.284 \\
\cline { 1 - 3 } INTIN4 $\rightarrow$ REIN4 & 0.345 & $0.170^{* *}$ & 0.170 & 0.055 \\
\cline { 1 - 3 } PESIN4 $\rightarrow$ REIN4 & -0.100 & 0.011 & & \\
\cline { 1 - 3 } EFADIN4 $\rightarrow$ REIN4 & -0.229 & 0.028 & & \multirow{2}{*}{0.016} \\
\hline EFADIN4 $\rightarrow$ PESIN4 & 0.248 & 0.039 & - & 0.059 \\
\hline
\end{tabular}

Note: INTIN4: Interested in Industry 4.0; EFADIN4: Effort for adaptation to Industry 4.0; REIN4: Readiness for Industry 4.0; PESIN4: Pessimism about Industry 4.0.; ${ }^{\star \star}: p<0.05$.

REIN4. Since REIN4 was only used as an independent variable, it does not have any latent variable to any dependent variable. Although PESIN4 did not have a significant relationship with INTIN4 and REIN4, it was not excluded from the model since it was determined that EFADIN4 had a significant effect on PESIN4. The results of $\mathrm{Q}^{2}$ being higher than zero proved that the structural model of the study had sufficient predictive relevance (Chin, 1998; Hair et al., 2014b). All the results of the variables having an effect on the model are summarized in Table 13.

\section{Discussion}

This empirical study surveyed the perception of university student on Industry 4.0. The analyses that should be applied in a scale development study were also applied in this study. In previous scale development studies, EFA and a reliability analysis were performed on the data obtained in the pilot study (Donnellan et al., 2006; Johanson \& Brooks, 2010; Demirci et al., 2014). Furthermore, in the main study (second part), convergent validity, discriminant validity, CFA, and structural model analyses were conducted, as in previous studies (Slavec \& Drnovsek, 2012; Magson et al., 2014; Solís \& Mora-Esquivel, 2019; Forsell et al., 2020).

In the research, a questionnaire with a 50-item pilot scale prepared for the measurement of industry 4.0 adaptation potential was conducted. As a result of the EFA of the data collected from the pilot scale, those items with a factor load lower than 0.550 were removed, and the number of items was reduced. The remaining 20 items were divided into four subdimensions, each containing five items, according to the factor relationships. These subdimensions were named as interested in Industry 4.0, effort for adaptation to Industry 4.0, readiness for Industry 4.0, and pessimism about Industry 4.0. The second stage of the research was carried out with this 20-item scale using EFA performed in IBM SPSS v. 25 and CFA performed in PLS-SEM. Based on the CFA results, items 10, 18, and 20 were removed from the scale, since their factor loadings were lower than 0.600 . Although, the loads of items 11 and 19 were lower than the recommended threshold value (0.708), they were not removed from the scale since they did not increase the relevant AVE value (Hair et al., 2014b). The structural model evaluation was performed on the remaining 17 items. The path coeffients, coefficients of determination $\left(R^{2}\right), f^{2}$ effect size, and predictive relevance $\left(Q^{2}\right)$ values were 
evaluated through the structural model (values shown in Tables 8-13). Although some of the independent variables in the model did not predict some of the dependent variables in a significant way, they were not excluded from the model because the same variable significantly predicted other variables. The results of structural model evaluation verified the model. All of the constructs were retained in the model.

As a result of the above analysis, the final form of 4IRAPS containing 17 items (Table 9) was developed to measure the potential of adaptation to Industry 4.0. Since, in the literature review, no scale was found to measure the potential of adapting to Industry 4.0 , the current study aimed to fill this gap and offer a valuable contribution to human resource management and practices in the context of Industry 4.0. The scale developed in this study will be a useful diagnostic tool for organizations and universities.

The limitations of the present study are a small sample and the scale consisting of only four subdimensions. Also the lack of cooperation with more than two experts in determining the parameters was another limitation. Therefore, it is recommended that future studies could contain a larger sample and determine more factors that influence the potential of adaption to Industry 4.0 .

\section{Conclusions}

The study aimed to develop a scale to measure the potential of adaptation to Industry 4.0. To achieve this, firstly, the literature was reviewed and a qualitative study was conducted to create items for a pilot scale. Then, a quantitative study was undertaken in two stages consisting of the pilot and main studies. Data was gathered from university students, and its validity and reliability with regard to measurement and structural model was proven by analyses. This study is important, being the first to develop a scale for the potential of adaptation to Industry 4.0 and for concluding that 4IRAPS can be used as a valid and reliable instrument in the assessment of individuals' potential of adaptation to Industry 4.0.

\section{Funding}

This work wasn't supported by any funding agency.

\section{Disclosure statement}

Author have no conflicts of interest to disclose.

\section{References}

Bauer, C., \& Wee, D. (2015, June 01). Manufacturing's next act. McKinsey \& Company. https://www. mckinsey.com/business-functions/operations/our-insights/manufacturings-next-act

Bauer, W., Schlund, S., Hornung, T., \& Schuler, S. (2018). Digitalization of industrial value chains - A review and evaluation of existing use cases of Industry 4.0 in Germany. Scientific Journal of Logistics, 14(3), 331-340. https://doi.org/10.17270/J.LOG.2018.288 
Charlton, E. (2019, January 14). These are the 10 most in-demand skills of 2019, according to LinkedIn. World Economic Forum. https://www.weforum.org/agenda/2019/01/the-hard-and-soft-skills-tofutureproof-your-career-according-to-linkedin/

Chin, W. (1998). Issues and opinions on structural equation modelling. MIS Quarterly, 22(1), 7-16. www.jstor.org/stable/249674

Crocker, L., \& Algina, J. (1986). Classical and modern test theory. Holt, Rinehart \& Winston.

Cronbach, L. J. (1951). Coefficient alpha and the internal structure of tests. Psychometrika, 16, 297-334. https://doi.org/10.1007/BF02310555

Demirci, K., Orhan, H., Demirdas, A., Akpinar, A., \& Sert, H. (2014). Validity and reliability of the Turkish Version of the smartphone addiction scale in a younger population. Bulletin of Clinical Psychopharmacology, 24(3), 226-234. https://doi.org/10.5455/bcp.20140710040824

Donnellan, M. B., Oswald, F. L., Baird, B. M., \& Lucas, R. E. (2006). The mini-IPIP scales: Tinyyeteffective measures of the Big Five factors of personality. Psychological Assessment, 18(2), 192-203. https://doi.org/10.1037/1040-3590.18.2.192

Eberhard, B., Podio, M., Alonso, A. P., Radovica, E., Avotina, L., Peiseniece, L., Sendon, M. C., Gonzales Lozano, A., \& Solé-Pla, J. (2017). Smart work: The transformation of the labour market due to the fourth industrial revolution (I4.0). International Journal of Business and Economic Sciences Applied Research (IJBESAR), 10(3), 47-66.

Field, A. P. (2009). Discovering statistics using SPSS. SAGE Publications.

Fornell, C., \& Larcker, D. F. (1981). Evaluating structural equation models with unobservable variables and measurement error. Journal of Marketing Research, 18(1), 39-50. https://doi.org/10.2307/3151312

Forsell, T., Tower, J., \& Polman, R. (2020). Development of a scale to measure social capital in recreation and Sport Clubs. Leisure Sciences, 42(1), 106-122. https://doi.org/10.1080/01490400.2018.1442268

Gorsuch, R. L. (1983). Factor analysis. Lawrence Erlbaum Associates.

Hair, J. F., Black, W. C., Babin, B. J., \& Anderson, R. E. (2014a). Multivariate data analysis: Pearson new international edition. Pearson Education Limited.

Hair, J. F., Hult, G. T. M., Ringle, C. M., \& Sarstedt, M. (2014b). A primer on partial least squares structural equation modeling (PLS-SEM). Sage Publication.

Hamada, T. (2019). Determinants of decision-makers' attitudes toward Industry 4.0 adaptation. Social Sciences, 8(5), 1-18. https://doi.org/10.3390/socsci8050140

Henseler, J., Ringle, C. M., \& Sarstedt, M. (2015). A new criterion for assessing discriminant validity in variance-based structural equation modeling. Journal of the Academy of Marketing Science, 43(1), 115-135. https://doi.org/10.1007/s11747-014-0403-8

Henseler, J., Ringle, C. M., \& Sinkovics, R. R. (2009). The use of partial least squares path modeling in international marketing. In R. R. Sinkovics \& P. N. Ghauri (Eds.), New Challenges to international marketing: Vol. 20. Advances in international marketing (pp. 277-320). Emerald Group Publishing Limited, Bingley. https://doi.org/10.1108/S1474-7979(2009)0000020014

Hertzog, M. A. (2008). Considerations in determining sample size for pilot studies. Research in Nursing \& Health, 31(2), 180-191. https://doi.org/10.1002/nur.20247

Isaac, S., \& Michael, W. B. (1995). Handbook in research and evaluation: A collection of principles, methods, and strategies useful in the planning, design, and evaluation of studies in education and the behavioral sciences (3 ed.). EdITS Publishers.

Johanson, G. A., \& Brooks, G. P. (2010). Initial scale development: Sample size for pilot studies. Educational and Psychological Measurement, 70(3), 394-400. https://doi.org/10.1177/0013164409355692

Koca, D. (2020). Sanayi devrimlerinin tarihsel arka planı ve işgücü becerileri üzerindeki yansımaları. OPUS International Journal of Society Researches, 16(31), 4531-4558.

https://doi.org/10.26466/opus.704841 
Leech, N. L., Barrett, K. C., \& Morgan, G. A. (2005). SPSS for intermediate statistics: Use and interpretation ( $2^{\text {nd }}$ ed.). Lawrence Erlbaum Associates. https://doi.org/10.4324/9781410611420

Magson, N. R., Craven, R. G., \& Bodkin-Andrews, G. H. (2014). Measuring social capital: The development of the social capital and cohesion scale and the associations between social capital and mental health. Australian Journal of Educational \& Developmental Psychology, 14, 202-216.

Pereira, A., \& Romero, F. A. (2017). Review of the meanings and the implications of the Industry 4.0 concept. Procedia Manufacturing, 13, 1206-1214. https://doi.org/10.1016/j.promfg.2017.09.032

Ringle, C. M., Wende, S., \& Becker, J.-M. (2015). SmartPLS 3. Boenningstedt: SmartPLS GmbH. http://www.smartpls.com

Robinson, J. P., Shaver, P. R., \& Wrightsman, L. S. (1991). Criteria for scale selection and evaluation. In J. P. Robinson, P. R. Shaver, \& L. S. Wrightsman (Eds.), Measures of personality and social psychological attitudes: Measures of social psychological attitudes (pp. 1-16). Academic Press. https://doi.org/10.1016/B978-0-12-590241-0.50005-8

Ruppert, T., Jaskó, S., Holczinger, T., \& Abonyi, J. (2018). Enabling technologies for Operator 4.0: A survey. Applied Sciences, 8(9), 1650. https://doi.org/10.3390/app8091650

Sanders, A., Elangeswaran, C., \& Wulfsberg, J. (2016). Industry 4.0 implies lean manufacturing: Research activities in Industry 4.0 function as enablers for lean manufacturing. Journal of Industrial Engineering and Management, 9(3), 811-833. https://doi.org/10.3926/jiem.1940

Schmidt, R., Möhring, M., Härting, R. C., Reichstein, C., Neumaier, P., \& Jozinovic', P. (2015). Industry 4.0 - potentials for creating smart products: Empirical research results. In W. Abramowicz (Ed.), Lecture notes in business information processing: Vol. 208. Business information systems (pp. 16-27). Springer International Publishing. https://doi.org/10.1007/978-3-319-19027-3_2

Slavec, A., \& Drnovsek, M. (2012). A perspective on scale development in entrepreneurship research. Economic and Business Review for Central and South-Eastern Europe, 14(1), 39-62.

Solís, M., \& Mora-Esquivel, R. (2019). Development and validation of a measurement scale of the innovative culture in work teams. International Journal of Innovation Science, 11(2), 299-322. https://doi.org/10.1108/IJIS-07-2018-0073

Stein, C. M., Morris, N. J., \& Nock, N. L. (2012). Structural equation modelling. In R. Elston, J. Satagopan, \& S. Sun (Eds.), Statistical human genetics: Methods and protocols. Methods in molecular biology (pp. 495-512). https://doi.org/10.1007/978-1-61779-555-8_27

Vaidya, S., Ambad, P., \& Bhosle, S. (2018). Industry 4.0-A glimpse. Procedia Manufacturing, 20(1), 233-238. https://doi.org/10.1016/j.promfg.2018.02.034

World Economic Forum. (2016). The Future of jobs: Employment, skills and workforce strategy for the fourth industrial revolution (Global Challenge Insight Report). http://www3.weforum.org/docs/ WEF_Future_of_Jobs.pdf

$\mathrm{Xu}, \mathrm{L}$. D., Xu, E. L., \& Li, L. (2018). Industry 4.0: State of the art and future trends. International Journal of Production Research, 56(8), 2941-2962. https://doi.org/10.1080/00207543.2018.1444806

Yaşlığlu, M. M. (2017). Factor analysis and validity in social sciences: Application of exploratory and confirmatory factor analyses. Istanbul University Journal of the School of Business, 46(Special Issue), 74-85. https://dergipark.org.tr/tr/pub/iuisletme/issue/32177/357061

Zhong, R., Xu, X., Klotz, E., \& Newman, S. (2017). Intelligent manufacturing in the context of Industry 4.0: A review. Engineering, 3(5), 616-630. https://doi.org/10.1016/J.ENG.2017.05.015 